\title{
EXPLANATION OF VOCATIONAL MUHKAM MUTASYABIH AND THE EXISTENCE OF MUHKAM WA MUTASYABIH
}

\author{
Nisa Nurzanah ${ }^{1}$, Hasbiyallah ${ }^{2}$, and Maslani ${ }^{3}$ \\ ${ }^{1}$ Postgraduate Program, UIN Sunan Gunung Djati, Bandung, nisanurzanah22@gmail.com \\ ${ }^{2}$ Postgraduate Program, UIN Sunan Gunung Djati, Bandung \\ ${ }^{3}$ Postgraduate Program, UIN Sunan Gunung Djati, Bandung
}

\begin{abstract}
We as Muslims are inseparable from the learning of the Holy Qur'an, because the Qur'an is the first and foremost source and legal basis. Therefore, the Qur'an is from various aspects. In reading the Koran there is also a verse called muhkam and mutasyabih. This research method uses a literature study, the author reads references from several literations, which are finally made as additional knowledge for the author. Wisdom verse muhkam means to facilitate the knowledge and purpose of the verse so that it is easy to practice the implementation of its teachings. The wisdom of the verse Mutasyabih is to add merit, because with so many verses it requires help and effort in expressing its intentions.
\end{abstract}

Keywords: Holy Qur'an, Muhkam, Mutasyabih

\begin{abstract}
Abstrak. Kita sebagai umat islam tidak terlepas dari pembelajaran kitab suci al-Qur'an, karena Al-Qur'an merupakan sumber dan dasar hukum yang pertama dan utama. Karenanya mempelajari Al-Qur'an dari berbagai aspek keilmuannya sangatlah penting. Dalam membaca al-Quran juga ada yang disebut ayat muhkam dan mutasyabih. Metode penelitian ini menggunakan studi pustaka, penulis membaca referensi dari beberapa literasi, yang akhirnya dijadikan sebagai
\end{abstract}


tambahan pengetahuan bagi penulis. Hikmah ayat muhkam yaitu memudahkan mengetahui arti dan maksud ayat agar mudah mengamalkan pelaksanaan ajaran-ajarannya. Hikmah ayat mutasyabih yaitu untuk menambah pahala, karena dengan adanya ayat ini mengharuskan penambahan daya dan upaya dalam mengungkapkan maksudnya.

Kata Kunci: Kitab Suci Al-Qur'an, Muhkam, Mutasyabih

\section{INTRODUCTION}

Allah sent down the Qur'an to His servants, in order to give guidance to the universe. Humans are created in a state of nature (holy), and the Qur'an is revealed with the holy verses contained therein. Therefore, between humans and the Qur'an have a harmonious and ideal relationship. Namely, as human provisions to understand the contents of the meaning and purpose of travel in world life.

Besides being a guide, the revelation of the Qur'an is present as a reminder for the universe and His creatures. He outlines for His creatures the true creed and straight principles in verses that are clear in their explanation and clear in their characteristics. They are His gifts to humanity. Where He establishes for them the points of religion to save their creed and explain the straight path they must travel. Al-Qur'an, is the main guiding part of the life of the people with which the eyes of the heart can open in every human being on earth.

The Divine Words, have been seen as life itself and not merely ordinary books. Kalam God is used as a guide and foothold in every aspect of human journey in the world and the hereafter.

But basically, sometimes the meaning of the Qur'an looks vague and not 
easy to be understood and understood by every human being. This is caused, because of the limitations of the mind and the ability of human effort, so it is so difficult to study the meaning and desire of the meaning of the verses. Therefore, we must know the meaning of muhkam mutasyabih and wisdom in learning it. Here the author will explain the explanation of muhkam mutasyabih with an easy-tounderstand presentation and the wisdom of the verse muhkam mutasyabih. The material related with Al Muhkam Wa Al mutasyabih, as one part of the Ulumul Qur'an's scholarship. Provide explanations and in-depth descriptions for guidance on understanding the intentions and desires of the verses of the Qur'an.

\section{DISCUSSION}

Understanding Muhkam defines as forbidding. Distinguish between the right and the false and the right and the lie. ${ }^{1}$ For example the meaning of the word واحكمتهالدابة/حكمت I punished the horse and I have sentenced him. This is an example of the Muhammadiyah verse because it needs an explanation of meaning. That is, there is the word حكمتwhich means "control". So if interpreted the whole meaning, I control the horse's mouth with a strong control so as not to run.

The Qur'an is entirely muhkam. That is, the words in the Qur'an are strong and sturdy, which distinguishes between the right and the false, the true and the lie.

According to the language Mutasyabih is taken from Arabic namely

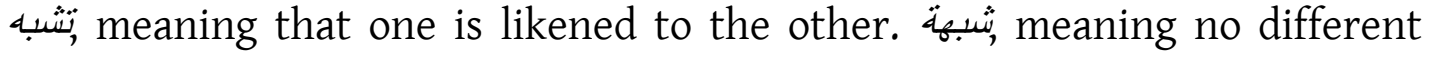
from the other. An example is taken in surah Al-Baqarah: 25 which means

\footnotetext{
${ }^{1}$ Halimuddin SH, Pembahasan Ilmu Al-Qur"an 2, (Jakarta: Rineka Cipta, 1995)
} 
"They are given similar fruits". That is, similar to each other in terms of color, not taste nor nature. Said to be similar in terms of words and deeds.

Tasyabuhkalam, that is similar and compatible, because it can be confirmed by one another. Allah makes the Qur'an as a whole, because it is similar according to this understanding. In surah Az-Zumar verse 23 which means "Allah has sent down the best words (i.e.) the same Qur'an (the quality of the verses) again and again.

The Qur'an is all mutasyabih. That is, between each other the verses are similar in terms of goodness and perfection. One justifies the other in terms of meaning.

Here can be seen a harmonious meeting between muhkam and mutasyabih. That muhkam and mutasyabih means absolute muqadam, not contradicting or denying each other. The contents of the verses of the Qur'an have the principles of the law of understanding that is strong and sturdy or muhkam. A strong and solid understanding, sustained by the relationship of attachment to the verses of the Qur'an that are appropriate and orderly. Complementing and justifying one verse from another (mutasyabih).

Meanwhile, in terms of scholars provide different definitions. As stated by. ${ }^{2}$ There are several meanings between muhkam and mutasyabih. First, muhkam is a verse whose meaning can be understood either real or through ta'wil. Whereas mutasyabih is a verse that is known by Allah, such as the problem of doomsday, the appearance of the Antichrist, and pieces of hijaiyah letters at the beginning of the second letter. Third, muhkam is a verse that contains only one ta'wil while mutasyabih is a verse that contains several possible ta'wil. Fourth, muhkam is a verse that stands alone while mutasyabih is a verse that is incomplete in

\footnotetext{
${ }^{2}$ Abidin Zainal, Seluk Beluk Al-Qur'an, (Jakarta: Rineka Cipta, 1992)
} 
understanding except by referring to another verse. Fifth, muhkam is a verse that is not written off while mutasyabih is a verse that has been written off.

So, it can be concluded that muhkam is a verse that can be interpreted as meaning, but mutasyabih cannot be adhered to because no one knows the ta'wil but Allah.

As for the reasons of the existence of the verse muhkam mutasyabih says that the cause of tasyabuh (disguise) in the Qur'an is broadly divided into 3 things. ${ }^{3}$ First, the obscurity of the aspect of lafadz verses is further divided into 2 namely the obscurity of lafadzmufrad which means the obscurity of a word lafadz, verse, which is seen from the lafadz side due to gharib (foreign) or multiple meaning (musytarak). The obscurity of lafadz murakkab, means an arrangement of lafadz that is difficult to understand.

Second, namely the obscene aspects of the meaning of the verse, because the meaning of lafadz is not reached by the human mind. Third, the blurring of lafadz from the meaning of the verse.

Example of verse Muhkam. As explained earlier, that muhkam is a clear verse, both lafadz and meaning so that it does not cause doubts and errors. Muhkamdoes not need ta'wil because it is clear. For example surah Al-Baqarah verse 21 which means "O people, worship your Lord who created you and those who were before you, so that you will fear Allah."

Example of mutasyabih verses. Mutasyabih verses are verses that are still vague in purpose and explanation. Therefore a ta'wil or interpretation is needed to explain the explanation of the verses. Example of the letter Thaha verse 5 which means "that is the Most Gracious God who dwells on arsy. Lafadz استشالعرش(Residing in 'Arshy) is interpreted as the highest place and declining over Him.

${ }^{3}$ Shihab Quraish, Kaidah Tafsir, (Tangerang: Lentera Hati, 2013) 
So, it can be concluded that the verse muhkam is a verse that is clear and does not require judgment but mutasyabih is lafadz or a verse that still requires judgment in order to understand the purpose of the verse explanation.

The following will be explained about the opinions of the scholars about the mutasyabih verse. The attitude of the scholars towards mutasyabih verses translated from the book.

Explain that differences of opinion of scholars are divided into two schools. First, the schools of salaf believe and believe in the verses of mutasyabih and give them entirely to Allah. Among the scholars who belonged to this group was Imam Maliki who came from the previous Ulama (mutaqaddimin). This method can be taken and followed, especially when there is fear of shaking of the beliefs of ordinary people in order to guard and fortify them from tasybih (likening Allah to His creatures) and they come from mutaakhirin (modern) scholars. ${ }^{4}$

The wisdom of the verse muhkam. Being a blessing for humans, especially for people whose Arabic language skills are weak, with the verses of muhkam whose meaning are clear, the benefits are great for them. Make it easy for humans to know the meaning and purpose, also makes it easy for them to live up to the meaning, meaning that it is easy to practice the implementation of his teachings. Encourage Muslims to actively understand, appreciate, and practice the contents of the Qur'an because the pronunciation of the verses is known, easy to understand and also clear to be practiced. Eliminating the difficulties and confusion of the people in learning the contents of the teachings, because the meaning of the pronunciation is clear meaning does not have to wait for the interpretation or explanation of the pronunciation of the verse or another surah.

The wisdom of mutasyabih, that is, to increase the reward, because with this 2001)

${ }^{4}$ Manna' Khalil Al-Khattan, Studi Ilmu-Ilmu Al-Qur'an, Trans., (Bogor: Lentera Antar Nusa, 
verse requires the addition of power and effort in revealing its meaning. As a mercy of Allah SWT for his servants who are unable to know everything. prove the miracle of the Qur'an, the height of literary science. The Qur'an contains the preachment to certain people and the public. Normal people usually don't like abstract things. Therefore the mutasyabih verse is present to explain the meaning of the verse in the Qur'an. So it can be concluded, that with the verses muhkam and mutasyabih become easier. Muhkam is a verse whose meaning is clear including its translation. However, the verse mutasyabih requires the condemnation of the scholars to find out the meaning of the verses in the Qur'an.

\section{CONLUSIONS}

From the results of the above writing, it can be concluded as follows: 1) muhkam means to forbid means to be able to distinguish between the right and the false. Mutasyabih means what is likened. So the verse is likened to its meaning. 2) Because verses muhkam mutasayabih according to Quraishshihab there are 3, namely the obscurity of lafadz verses, the obscurity of lafadz from the meaning of verses, and the security of lafadz from the meaning of verses. 3) The wisdom of the verse muhkam is to make it easier for people to find out the meaning of the verse. While the wisdom of the existence of mutasyabih verses is to increase the reward because with this verse requires the addition of power and effort in expressing their intentions.

\section{REFERENCES}

SH., Halimuddin, Pembahasan Ilmu Al-Qur'an 2, Jakarta: Rineka Cipta, 1995. Abidin, Zainal, Seluk Beluk Al-Qur'an, Jakarta: Rineka Cipta, 1992. 
Jurnal Hunafa: Studia Islamika, Volume 16, Number 2, p. 1- 150

E-ISSN: 2355-7710

P-ISSN: 1411-125X

Shihab, Quraish, Kaidah Tafsir, Tangerang: Lentera Hati, 2013.

Djalal, Abdul, Ulumul Qur'an, Surabaya: Dunia Ilmu, 2008.

Al Khattan, Manna' Khalil, Studi Ilmu-Ilmu Al-Qur'an, (Sukardi AS., Trans), Bogor: Lentera Antar Nusa, 2001.

"Pengertian ayat muhkam dan mutasyabih dalam Al-Qurn'an.", http://www.jadipintar.com/2015/02/pengertian-ayat-muhkam-dan-mutasyabbihdalam-al-quran.html, Accessed 09 July 2019. 